\title{
PENERAPAN IMPLIKASI MODEL PEMBELAJARAN THE CLASSICAL DALAM MENINGKATKAN PRESTASI BELAJAR MATERI POKOK KETENTUAN UUD NKRI TAHUN 1945 DALAM KEHIDUPAN BERBANGSA DAN BERNEGARA PESERTA DIDIK DI KELAS X SMA NEGERI 1 ANGKOLA SELATAN TAHUN PELAJARAN 2017-2018
}

\section{Putoro Dongoran}

FKIP Univeristas Muhammadiyah Tapanuli Selatan

\begin{abstract}
Abstrak
Rumusan masalah dalam penelitian ini adalah apakah ada penerapan implikasi model pembelajaran The Classical dalam meningkatkan prestasi belajar materi pokok ketentuan UUD NKRI Tahun 1945 dalam kehidupan berbangsa dan bernegara peserta didik di kelas X SMA Negeri 1 Angkola Selatan Tahun Pelajaran 2017-2018?. Sedangkan tujuan penelitian yaitu untuk memperdalam atau memperluas pengetahuan penulis sendiri mengenai penggunaan penerapan implikasi model pembelajaran The Classical dalam meningkatkan prestasi belajar materi pokok ketentuan UUD NKRI Tahun 1945 dalam kehidupan berbangsa dan bernegara peserta didik di kelas X SMA Negeri 1 Angkola Selatan. Berdasarkan hasil dari perhitungan yang dilakukan dengan menggunakan rumus "Product Moment" maka dapat dilihat bahwa nilai rhitung lebih besar dari nilai rtabel yaitu 0,964 > 0,349.
\end{abstract}

Kata Kunci: Model Pembelajaran, Undang Undang NKRI, Prestasi Belajar

\section{Pendahuluan}

Pancasila sebagai Dasar Negara mempunyai kedudukan dan peran penting sebagai dasar Filsafat negara. Dengan kedudukan Pancasila yang seperti itu Pancasila sebagai pondasi atau dasar dalam melakukan sebuah kegiatan berbangsa dan bernegara. Pancasila sebagai suatu sistem Filsafat pada hakikatnya merupakan suatu nilai yang bersumber dari tingkah laku (adat - istiadat) masyarakat

Indonesia. Suatu pemikiran - pemikiran yang bersifat kritis, mendasar sistematis dan komprehensif (menyeluruh) dan sistem pemikiran ini merupakan suatu nilai. Oleh karena itu suatu pemikiran Filsafat tidak secara langsung menyajikan norma - norma yang merupakan pedoman dalam suatu 
tindakan atau suatu nilai yang bersifat mendasar.

Nilai - nilai Pancasila kemudian dijabarkan dalam suatu norma yang jelas sehingga merupakan suatu pedoman.Norma tersebut meliputi norma Agama, Kesusilaan, Kesopanan dan Hukum. Dalam pengertian inilah maka pancasila berkedudukan sebagai sumber dari segala hukum di Indonesia, pancasila juga merupakan suatu cita - cita moral yang luhur yang terwujud dalam kehidupan sehari - hari bangsa Indonesia sebelum membentuk Negara dan berasal dari bangsa Indosesia sendiri sebagai asal mula (kausa materialis).

Politik di Negara Indonesia kini telah banyak jauh dari sifat pancasila. Politik yang menjadi alat perjuangan rakyat dalam mempertahankan hak - haknya sekarang telah bergeser menjadi suatu komuditas yang menjadikan kekuasaan serta harta yang melimpah bagi pelakunya. Kita seakan akan hanya bisa melihat dan diam tak berdaya ketika elite politik sibuk menguasai tentang harta, serta kepentingan golongannya saja dan acuh - tak acuh melihat keadaan berjuta masyarakat Indonesia yang menangis kelaparan. Oleh sebab itu dalam skripsi ini akan dibahas tentang hubungan etika berpolitik dalam pancasila.

Berdasarkan pra penelitian yang penulis lakukan di SMA Negeri 1 Angkola Selatan menunjukkan bahwa model pembelajaran yang dilakukan oleh guru masih mempergunakan model pembelajaran tradisional adalah model pembelajaran yang dilakukan guru dengan ceramah tanpa memberikan kesempatan kepada peserta didik dan berpusat pada guru. Berdasarkan KKM yang ditentukan sekolah adalah 72, ternyata masih banyak peserta didik belum memperoleh nilai baik. Ini terlihat dari nilai yang di peroleh peserta didik dari prapenelitian yang dilakukan penulis. Jumlah peserta didik 30 orang ternyata 10 orang peserta didik memperoleh nilai dibawah KKM dengan 30\% dan di atas nilai KKM sebanyak 20 orang peserta didik bila di persentasekan 70\%. Sesuai dengan uraian di atas maka penulis berkeinginan melakukan penelitian di SMA Negeri 1 Angkola Selatan sesuai dengan judul penelitian diatas.

\section{Metode Penelitian}

Penelitian ini akan di laksanakan tiga bulan sejak dikeluarkannya surat permohonan izin penelitian dari Dekan Fakultas Keguruan dan Ilmu Pendidikan Universitas Muhammadiyah Tapanuli Selatan. Dalam penelitian ini penulis memfokuskan pada dua variabel yaitu penggunaan model pembelajaran The Classical sebagai (X) dan sebagai variable (Y) prestasi belajar peserta didik. Dalam melakukan penelitian ini, penulis menggunakan pendekatan Pendekatan penelitian kepustakaan (Library Researct) dan Penelitian lapangan (Field Research). Dalam penelitian ini penulis menggunakan penelitian asosiatif yaitu merupakan penelitian yang bertujuan untuk mengetahui pengaruh ataupun juga hubungan antara dua atau lebih variabel. 


\section{Pembahasan dan Hasil}

$\begin{array}{ccr} & \text { Model Pembelajaran Pembaharuan } \\ \text { dapat } & \text { Membantu Dalam Proses }\end{array}$
Pembelajaran Pendidikan Pancasila dan Kewarganegaraan (PPKn) terdapat responden yang menjawab $\mathrm{Ya}=20$ peserta didik (66,67\%), sedangkan yang menjawab Kadang - kadang terdapat $=7$ peserta didik (23,23\%), dan yang menjawab Tidak 3 peserta didik atau sebesar 10,10\%. Model Pembelajaran The Classical dianggap Baik terdapat responden yang menjawab $\mathrm{Ya}=23$ peserta didik (76,67\%), sedangkan yang menjawab Kadang - kadang terdapat $=4$ peserta didik (13,33\%), dan yang menjawab Tidak 3 peserta didik atau sebesar 10,00\%.

Model Pemblejaran The Classical Dalam Bidang Studi Pendidikan Pancasila dan Kewarganegaraan (PPKn) terdapat respondenyang menjawab $\mathrm{Ya}=18$ peserta didik (60,00\%), menyatakan bahwa guru PPKn yang menggunakan model pembelajaran The Classical tidak selalu dapat menciptakan interaksi guru dengan peserta dan Kadang - kadang $=8$ peserta didik (26,67\%), sedangkan yang menjawab Tidak $=4$ peserta didik atau sebesar $13,33 \%$.

Dari perhitungan koefisien korelasi Product Moment tersebut maka $r$ hitung nya adalah sebesar 0,96. Hasil ini kemudian di bandingkan dengan dimana $r$ table lebih besar dari $r$ hitug yaitu 0,96 > 0,349 (taraf kesalahan 5\%) dan 0,94>0449 (pada taraf kesalahan 1\%) maka dapat dikatakan. Dari perhitungan di atas, maka hipotesis yang penulis ajukan dapat diterima kebenarannya
Dengan terkumpulnya data dalam penelitian ini yang diperoleh di SMA Negeri 1 Angkola Selatan dengan teknik angket penerapan model pembelajaran The Classical model dalam meningkatkan prestasi belajar materi pokok ketentuan UUD NKRI tahun 1945 dalam kehidupan berbangsa dan bernegara, angket tersebut disebarkan kepada peserta didik guna mendapatkan data tentang pernerapan model pembelajaran The Classical model dalam meningkatkan prestasi belajar materi pokok ketentuan UUD NKRI tahun 1945 dalam kehidupan berbangsa dan bernegara peserta didik di kelas X SMA Negeri 1 Angkola Selatan Tahun Pelajaran 2017-2018.

\section{Kesimpulan}

Berdasarkan dari hasil pengolahan data Maka diperoleh hasil rhitung $=0,964$ hasil ini kemudian dibandingkan dengan rtabel $=0,349$ dimana lebih besar dari rtabel 0,964 > 0,349, dapat dikatakan bahwa hipotesis $\mathrm{Ha}_{\mathrm{a}}$ diterima dan $\mathrm{H}_{\mathrm{o}}$ ditolak, maka ada penerapan model pembelajaran The Classical model dalam meningkatkan prestasi belajar materi pokok ketentuan UUD NKRI tahun 1945 dalam kehidupan berbangsa dan bernegara peserta didik di kelas X SMA Negeri 1 Angkola Selatan Tahun Pelajaran 2017-2018.

\section{Saran}

Berdasarkan penelitian yang dilakukan maka penulis menyampaikan saran sebagai berikut : 
1. Kepada para guru hendaknya dapat meningkatkan dan mengembangkan kualitas mengajarnya sehingga dapat menjadi pengalaman dalam mengajar.

2. Hendaknya guru mengawasi kegiatan peserta didik terutama yang berhubungan dengan kegiatan belajarnya, dengan demikian peserta didik akan merasa diperhatikan oleh guru.

3. Diharapkan adanya kerjasama yang baik antara orang tua peserta didik dan pihak sekolah dalam upaya untuk meningkatkan prestasi belajar peserta didik.

\section{Daftar Pustaka}

\begin{tabular}{ccc}
\multicolumn{2}{c}{ Syafruddin Azwar, } & Metode \\
Penelitian, $\quad$ Yogyakarta: & Pustaka
\end{tabular}

Pelajar.Tahun 2010

Iskandar Widi, Metode Penelitian, Yogyakarta:Graha Ilmu.Tahun 2010

$\begin{array}{cccr}\text { Murti } & \begin{array}{c}\text { Sumarni } \\ \text { Wahyudi, }\end{array} & \text { Metodologi } & \begin{array}{r}\text { Salman } \\ \text { Penelitian }\end{array}\end{array}$ Bisnis, Yogyakarta:

Penerbit Andi. Tahun 2006

M Irfan Islam Prinsip-Prinsip Perumusan Kebijakan Negara. Tahun 2002 Kumandar, Guru/Profesional/Implementasi Kurikulum Tingkat Satuan Pelajaran (KTSP) dan Sukses dalam Sertifikasi Guru, Jakarta Raja Grafindo Persada ,Tahun 2007

Prof.Dr. Aunurrahman, Belajar dan Pembelajaran,, Alfabeta,Tahun 2013
Donal, Psikologi

Belajar, Jakarta:2004, Rineka Cipta

Muhibbin Syah, Psikologi Belajar, Jakarta Raja Grapindo Persada Tahun 2003

Gegne,Metode Pembelajaran, Bandung: Bumi Aksara, 2012

James O. Whittaker, Belajar dan Pembelajaran, Jakarta: Remaja Rosdakarya, 2004

Cronbach,Belajar dan Pembelajaran, Bandung : Alpabeta, 2007

Istarani \& Intan Pulungan, Ensiklopedi Pendidikan ,Medan:MediaPersa da 2015.

Sugiyono, Metode penelitian Administrasi,Bandung: Alfabeta,2007 